\title{
CINTA DAN KEBENARAN ALLAH: CAHAYA UNTUK MENERANGI KEHIDUPAN MANUSIA \\ Uraian Teologis atas Pandangan Paus Fransiskus dalam Ensiklik Lumen Fidei, Bab II, "Jika Engkau Tidak Percaya, Maka Engkau Tidak Akan Mengerti”
}

\author{
Alfonsus Ara*
}

\begin{abstract}
Abstrak
Dunia membutuhkan kebenaran agar bisa membangun kehidupan yang harmonis dan damai. Namun, kebenaran yang dipegang teguh oleh dunia adalah kebenaran yang subyektif, bukan kebenaran yang obyektif sebab kebenaran-kebenaran itu lahir dari pemikiran manusia. Dunia membutuhkan kebenaran yang obyektif, yaitu kebenaran yang bersumber dari Allah. Kebenaran Allah tidak sesat (tidak salah) sebab bersumber dari cinta-Nya. Cinta Allah adalah kebenaran dan kebenaran Allah adalah kebenaran cinta. Cinta Allah adalah kebenaran sebab dinyatakan dalam tindakan-Nya, yaitu setia memberikan isi cinta-Nya demi keselamatan manusia.
\end{abstract}

Kata-kata Kunci: Allah, Cinta, Kebenaran, Tindakan, kesetiaan, Hati, Cahaya, Keselamatan, Kebahagiaan

\section{Pengantar}

Dalam ensikliknya, Lumen Fidei, Paus Fransiskus mengingatkan dunia mengenai pentingnya cinta dan kebenaran untuk membangun persekutuan hidup yang bermakna, akrab, harmonis, penuh persaudaraan dan kedamaian. Cinta selalu memberikan pencerahan karena terikat dengan kebenaran. Sebuah kebenaran hanya mampu memberikan arti bagi perjalanan hidup manusia apabila kebenaran itu berakar pada cinta.

Cinta bukan hanya gerakan perasaan yang fana sebab hakekat cinta yang otentik adalah pengalaman akan kebenaran yang terarah 
seutuhnya pada persatuan dengan yang dicintai. Hakekat cinta ini akan membuka mata setiap manusia untuk melihat dunia dengan cara yang baru dan benar, yaitu dunia kehidupan yang dibangun atas persekutuan hidup antar pribadi yang saling mencintai satu dengan yang lain. Apabila persekutuan hidup ini dibangun atas wadas cinta, maka dunia ini menjadi kediaman yang nyaman, damai dan harmonis karena dihuni oleh insan pencinta.

\section{Landasan Iman dari Cinta dan Kebenaran}

\section{Allah adalah Cinta}

Allah adalah cinta. Kodrat diri Allah yang adalah cinta nyata dalam Sabda-Nya dan penyataan diri-Nya kepada manusia yang merupakan mahkota ciptaan-Nya sendiri. Allah menciptakan manusia dengan kekuatan "Sabda-Nya yang kreatif", yaitu "Sabda Cinta-Nya" (Sabda Allah adalah Sabda Cinta) dan memperlakukan manusia sebagai pribadi: Allah memanggil dan menyapa manusia dengan nama yang unik. $^{1}$

Penciptaan manusia dengan Sabda kreatif Allah menyatakan bahwa Allah mengawali penciptaan manusia dengan sebuah "dialog". Dasar keyakinan iman ini dilukiskan dalam formulasi biblis yang dilukiskan dalam kisah penciptaan pada hari keenam: "Baiklah kita menjadikan manusia serupa dengan kita". Kata "kita" dalam rumusan ini mengandung arti bahwa "Allah dalam kemahakuasaan-Nya berSabda/ber-Bicara dengan diri-Nya sendiri untuk menciptakan dan

${ }^{1}$ Bdk. Paus Benediktus XVI, Ensiklik Deus Caritas Est, diterjemahkan oleh Piet Go, O.Carm (Jakarta: Dokpen KWI 2005), no. 1, hlm. 5-6; Bdk. Paus Fransiskus, Ensiklik Lumen Fidei, diterjemahkan oleh Alb. Deby Setiyanto (Yogyakarta: Kanisius 2014), no. 26-27, hlm. $42-45$ (Dalam penulisan selanjutan, Ensiklik Lumen Fidei ini disingkat dengan Lumen Fidei). 
Alfonsus Ara, Cinta dan Kebenaran Allah ...

menjadikan manusia sebagai gambaran/citra atau potret diri-Nya sendiri. $^{2}$

Rumusan ini menegaskan keberadaan manusia sebagai isi diri dan hidup Allah sendiri sebab diciptakan dari Sabda Cinta Allah sendiri. Manusia menjadi puncak dan tujuan dari semua ciptaan sebab dalam diri manusia maksud Allah terhadap semua ciptaan-Nya sungguhsungguh terlaksana, yaitu dialog cinta antara Allah dengan ciptaan-Nya. Hanya manusia yang mampu menanggapi dialog cinta Allah dengan penuh kesadaran, kebebasan dan kepribadian yang utuh. ${ }^{3}$

Penciptaan manusia dengan Sabda kreatif-Nya juga menyatakan bahwa dalam diri manusia, Allah menggoreskan isi cinta-Nya. Allah menghendaki agar: pertama, manusia menjadi insan pencinta; kedua, manusia menjadi saksi bagi semua ciptaan akan rahmat fundamentalNya sebagai Sang Pencipta, yaitu saksi mengenai cinta-Nya yang menjadi sumber dan landasan hidup antara manusia dengan-Nya, manusia dengan sesamanya dan manusia dengan alam semesta; ketiga, manusia membangun persekutuan hidup dengan Allah dan sesama berlandaskan pada cinta dan kelanggengannya ditentukan oleh kesetiaan. 4

Inti persekutuan cinta antara Allah dengan manusia dan manusia dengan sesamanya dinyatakan dalam sebuah pewahyuan bahwa Allah sangat mencintai umat-Nya (bdk. Hosea 2,21; Yeremia 3,6-13; Yesaya 54). Allah hadir dan membangun kediaman-Nya di tengah kehidupan

2 Bdk. Paus Benediktus XVI, Ensiklik Caritas In Veritate (Kasih dalam Kebenaran), diterjemahkan oleh B. R. Agung Prihartana, MSF (Jakarta: Dokpen KWI 2014), no. 4, hlm. 7-8.

3 Bdk. Paus Yohanes Paulus II, Anjuran Apostolik mengenai Peranan Keluarga Kristen dalam Dunia Modern Familiaris Consortio, diterjemahkan oleh R. Hardawiryana (Jakarta: Departemen Dokumentasi dan Penerangan KWI 1993), no. 12, hlm. 25. (Dalam penulisan selanjutan, Anjuran Apostolik ini disingkat dengan Familiaris Consortio).

${ }^{4}$ Bdk. Paus Yohanes Paulus II, Familiaris Consortio..., no. 12, hlm. 25. 
manusia untuk meneguhkan persekutuan cinta-Nya dengan manusia. Allah menyatakan kepada manusia bahwa cinta-Nya adalah daya pemersatu antara manusia dengan diri-Nya dan manusia dengan sesamanya serta fundamen bagi manusia untuk memperoleh keselamatan dan kebahagiaan, keharmonisan dan kedamaian. Cinta menggerakan manusia untuk mengasihi Allah serta saling mengasihi dengan seluruh diri satu terhadap yang lain. ${ }^{5}$

Walaupun demikian, patut diakui bahwa dialog cinta antara Allah dan manusia selalu memiliki hambatan sebab manusia kerap tidak menjawab komunikasi diri Allah sebagaimana yang diinginkan Allah sendiri. Oleh karena itu, dengan kekuatan cinta-Nya, Allah berinisiatif menjalin dialog yang sempurna dengan manusia dalam inkarnasi-Nya menjadi manusia. ${ }^{6}$

Dalam peristiwa penjelmaan, Sabda kekal Allah sendiri menjadi manusia yang paling sempurna untuk menuntun manusia agar mampu memberikan jawaban yang sempurna terhadap dialog cinta dengan Allah. Dengan demikian ditegaskan bahwa melalui Sabda-Nya yang menjelma menjadi manusia, yaitu Yesus Kristus, hakekat Allah yang adalah cinta mencapai puncak kepenuhan-Nya. Dia adalah yang sulung, yang pertama dan utama dari semua ciptaan. Segala sesuatu diciptaan di dalam Dia dan melalui Dia: "karena begitu besar kasih Allah akan dunia ini, sehingga Ia telah mengaruniakan AnakNya yang tunggal, supaya setiap orang yang percaya kepadaNya tidak binasa, melainkan beroleh hidup yang kekal" (Yoh 3:16).

Keyakinan iman ini meresap dan merasuk dalam seluruh inti pengalaman hidup manusia yang menerima dan membatinkan kebenaran cinta-Nya. Cinta Allah dalam diri Yesus Kristus adalah kebenaran karena sungguh-sungguh dinyatakan dalam kesetiaan dan kerelaan-Nya untuk memberikan diri dan hidup-Nya sendiri demi

\footnotetext{
${ }^{5}$ Bdk. Paus Yohanes Paulus II, Familiaris Consortio..., no. 12, hlm. 25.

${ }^{6}$ Bdk. Paus Benediktus XVI, Ensiklik Caritas In Veritate..., no. 4, hlm. 7-8.
} 
Alfonsus Ara, Cinta dan Kebenaran Allah ...

keselamatan manusia. Cinta Allah dalam diri Yesus Kristus adalah kebenaran karena merangkum semua manusia sebagai saudara dan menjadi tempat sandaran yang aman bagi semua manusia yang mencari kebahagiaan dan ketenteraman hidup. Cinta Allah dalam diri Yesus Kristus adalah kebenaran sebab dinyatakan dalam kerelaan-Nya untuk keluar dari diri-Nya sendiri dan terarah kepada manusia, mahkota ciptaan-Nya sendiri. ${ }^{7}$

Isi pengakuan iman ini juga menggerakan manusia untuk membuka diri pada kuasa cinta-Nya: manusia berasal dari cinta, dipanggil untuk bergerak menuju terang karena cinta serta diutus untuk hidup dalam kuasa cinta dan saling mencintai. Hanya ketika manusia hidup dalam kuasa cinta, maka manusia tetap berada dalam terang. ${ }^{8}$

\section{Allah adalah Kebenaran}

Allah adalah Amin: "Allah Kebenaran" (bdk. Yes 65:16), "dasar janji kesetiaan yang kokoh". Dia adalah batu karang yang teguh dan dapat dipercaya. Kebenaran-kebenaran Allah itu nyata dalam setiap rencana dan tindakan-Nya untuk memenuhi janji-janji-Nya kepada manusia demi keselamatan dan kebahagiaan manusia sendiri. Semua rencana-Nya indah. Dalam rencana-Nya yang indah itu, Dia menyatakan diri-Nya dan kebenaran-Nya yang menjadi sandaran bagi manusia. Kebenaran Allah itu nyata dalam pemberian cinta-Nya yang berpuncak pada kehadiran-Nya yang setia dalam sejarah-sejarah kehidupan manusia. Allah menyatukan waktu dan zaman serta mengumpulkan semua alur kehidupan manusia yang tercerai berai dalam persekutuan cinta dengan-Nya. ${ }^{9}$

\footnotetext{
${ }^{7}$ Lumen Fidei..., no. 28, hlm. 46.

${ }^{8}$ Lumen Fidei..., no. 28, hlm. 46.

${ }^{9}$ Lumen Fidei..., no. 23, hlm. 37-39.
} 
Kebenaran-kebenaran Allah memberikan pijakan yang pasti kepada manusia untuk menggapai keselamatan dan kebahagiaan. Allah adalah kebenaran itu sendiri dan seluruh kebenaran-Nya nyata dalam kesetiaan-Nya. Karena kebenaran iman ini, Paus Fransiskus menjelaskan bahwa kebenaran dan kesetiaan selalu berjalan bersama: Allah yang benar adalah Allah selalu setia pada janji-janji-Nya. Kebenaran Allah mencakup seluruh dunia dan melampaui batas sejarah kehidupan manusia. ${ }^{10}$

Allah, sumber segala kebenaran menyatakan isi kebenaran-Nya secara tuntas dan sempurna dalam Sabda-Nya yang menjelma menjadi manusia, yaitu Putera Tunggal-Nya sendiri, Yesus Kristus. Karena itu, beriman pada kebenaran-kebenaran Allah menuntut manusia untuk selalu mendengarkan Sabda-Nya. Dalam Sabda-Nya, Allah menyatakan kebenaran-Nya, yaitu kesetiaan-Nya pada janji-Nya untuk menyelamatkan manusia. ${ }^{11}$

Kebenaran-kebenaran Allah hanya bisa dikenal dan dimengerti apabila manusia membuka diri untuk mendengarkan Sabda-Nya sebab "iman datang dari pendengaran" (Rom 10,17). Pengetahuan mengenai kebenaran-kebenaran iman yang lahir dari pendengaran ini bersifat pribadi sehingga dengan penuh kebebasan, pribadi yang mendengarkan Sabda-Nya patuh untuk mengikuti-Nya. ${ }^{12}$

Kebenaran-kebenaran iman yang lahir dari pendengaran pribadi atas Sabda-Nya diteguhkan oleh penglihatan atas pekerjaan-pekerjaan yang dilakukan-Nya untuk menyatakan keagungan dan kemuliaan Allah. Pendengaran dan penglihatan akan membawa manusia kepada gambaran yang utuh dan mendalam mengenai landasan kebenaran itu sendiri. "Jikalau engkau percaya engkau akan melihat kemuliaan Allah"

\footnotetext{
${ }^{10}$ Lumen Fidei..., no. 28, hlm. 46.

${ }^{11}$ Lumen Fidei..., no. 28, hlm. 46.

12 Lumen Fidei..., no. 29, hlm. 47-49.
} 
Alfonsus Ara, Cinta dan Kebenaran Allah ...

(Yoh 11: 40). Yesus Kristus adalah sosok historis yang bisa dilihat dan didengar. Dia adalah Sabda yang menjadi daging untuk menyatakan wajah Allah yang mulia dan agung kepada dunia. Inti kebenaran iman yang tidak terbatalkan adalah "pewahyuan Bapa dalam Putera dalam rupa daging dan tindakan duniawi-Nya, sebuah kebenaran yang diartikan sebagai 'kehidupan yang dipenuhi cahaya" ${ }^{13}$

Kebenaran-kebenaran Allah yang dinyatakan dalam Sabda-Nya menegaskan bahwa kebenaran iman itu "tidak mengarahkan penglihatan kita pada kebenaran yang semata datang dari dalam diri". Kebenaran iman adalah kebenaran yang bersumber pada perjumpaan dengan Allah dalam diri Yesus Kristus yang adalah kebenaran itu sendiri. ${ }^{14}$

\section{Tautan antara Hati, Cinta dan Kebenaran}

\section{Hati}

Menurut Paus Fransiskus, semua pengetahuan mengenai kebenaran Allah bersumber pada cinta Allah kepada manusia. Allah yang diimani umat manusia dan menerangi jalan hidup manusia adalah cinta dan setia. ${ }^{15}$

Paus menjelaskan bahwa jenis pengetahuan pertama yang berkaitan dengan kebenaran adalah pengetahuan yang bersumber dari hati manusia. Pengetahuan iman yang bersumber dari hati sungguhsungguh memiliki kebenaran sebab "dengan hati orang percaya" (Roma 10:10). Hati adalah inti kepribadian dan tempat semua dimensi kemanusiaan, yaitu tubuh dan jiwa, keterbukaan pada dunia dan pada yang lain. Hati juga menjadi tempat bertumbuhnya perasaan, kehendak

\footnotetext{
13 Lumen Fidei..., no. 30, hlm. 49-51.

14 Lumen Fidei..., no. 30, hlm. 51.

15 Lumen Fidei..., no. 26, hlm. 42-43.
} 
dan daya intelektual. Hati mampu menampung semua dimensi manusiawi karena selalu terbuka terhadap kebenaran dan cinta. ${ }^{16}$

Karena hati adalah inti dan pusat kepribadian manusia, maka semua pengetahuan mengenai kebenaran-kebenaran Allah justru ada dan bersumber di kedalaman hati manusia. Pengetahuan mengenai kebenaran Allah itu muncul ketika hati manusia disentuh. Apabila hati manusia disentuh dan tersentuh, maka totalitas kemanusiaannya akan terbuka terhadap kehadiran batin yang lain serta memberdayakannya untuk mengenali misterinya. "Iman muncul ketika hati manusia disentuh". Santo Yohanes memberikan kesaksiannya mengenai iman yang muncul, hidup dan berkembang karena sentuhan kasih yang Ilahi dengan kesaksiannya, “Apa yang telah kami dengar, yang telah kami lihat dengan mata kami, yang telah kami raba dengan tangan kami tentang Firman Hidup" (I Yoh 1:1). ${ }^{17}$

Melalui kehadiran-Nya dan kerelaan-Nya untuk tinggal bersama manusia, Yesus menyentuh hati dan kehidupan manusia dengan Sabda dan tindakan-Nya. Sentuhan kasih-Nya mengubah hati dan kehidupan manusia serta memberdayakan manusia untuk mengenal dan mengakui-Nya sebagai Putera Allah. Hati yang disentuh oleh daya kasih-Nya ini akan terbuka untuk menerima kekuatan rahmat-Nya. Pengalaman ini nyata dalam diri seorang perempuan yang menderita pendarahan. Dia memperoleh kesembuhan ketika dia "menyentuh dengan hatinya" (bdk. Luk 8:45-46). ${ }^{18}$

Bagi Paus Fransiskus, "menyentuh dengan hati" berarti "percaya". Sentuhan dengan hati berarti sentuhan dengan seluruh diri hingga akhirnya manusia menyerahkan diri penuh kepasrahan kepada kuasa ilahi-Nya serta berjuang untuk menyelaraskan diri dengan Sabda

\footnotetext{
16 Lumen Fidei..., no. 26, hlm. 42-43.

17 Lumen Fidei..., no. 31, hlm. 51-53.

18 Lumen Fidei..., no. 31, hlm. 51-53.
} 
Alfonsus Ara, Cinta dan Kebenaran Allah ...

Yesus. Dengan menyentuh Yesus, wanita itu percaya. Dia menerima mata yang dibutuhkannya untuk melihat Yesus. Berbeda dengan wanita yang mengalami sakit pendarahan, kerumunan orang banyak yang mendesak Yesus, namun tidak meraih-Nya dengan sentuhan iman personal, hati mereka pun tidak terbuka untuk percaya bahwa Dia adalah Putera Allah. ${ }^{19}$

Iman adalah pilihan hati yang paling fundamental dalam kehidupan manusia. Dengan beriman, manusia memberikan tempat kepada Allah dalam hati dan kehidupannya serta membiarkan semua pengetahuan mengenai kebenaran-Nya masuk dan merasuki inti pengalaman hidupnya sebagai manusia. Semua pengetahuan iman yang bersumber dan berakar di hati adalah pengetahuan yang benar dan tidak sesat sebab kebenaran yang lahir dari hati adalah kebenaran cinta. Inti kebenaran iman merupakan buah dari perjumpaan personal dengan Allah, Sang Sumber Kebenaran dan Sumber Cinta serta perjumpaan dengan sesama. Kebenaran ini akan membebaskan manusia dari keterkurungan diri sehingga menjadi bagian dari kesejahteraan umum. ${ }^{20}$

Karena kebenaran yang bersumber di hati adalah kebenaran cinta, maka kebenaran itu tidak dapat dipaksakan dan tidak menghalangi kebebasan pribadi. Kebenaran ini justru merasuk di dalam hati atau ke dalam inti pribadi manusia sendiri. Kebenaran itu akan mengubah manusia menjadi pribadi yang rendah hati karena manusia sungguh-sungguh mengerti dan percaya bahwa bukan dirinya yang memiliki kebenaran, melainkan karena kebenaran iman itu sendirilah yang memeluk dan memilikinya. ${ }^{21}$

\footnotetext{
${ }^{19}$ Lumen Fidei..., no. 31, hlm. 51-53.

${ }^{20}$ Lumen Fidei..., no. 32-33, hlm. 53-56.

${ }^{21}$ Lumen Fidei..., no. 34, hlm. 56-58.
} 


\section{Cinta dan Kebenaran}

Pengetahuan iman yang bersumber dalam hati manusia akan mengubah sikap dan kehidupan iman manusia beriman secara menyeluruh. Namun, Paus Fransiskus menjelaskan bahwa daya perubahan itu hanya mungkin terjadi apabila pengetahuan mengenai kebenaran iman itu terbuka pada cinta. ${ }^{22}$

Menurut paus, pengetahuan mengenai kebenaran iman yang bersumber dan terbuka pada cinta memiliki daya untuk meyakinkan dan menerangi langkah hidup pribadi yang beriman. Iman yang terikat pada cinta akan memberikan pencerahan. Iman yang demikian lahir, tumbuh dan berkembang ketika pribadi yang beriman menerima dan mengalami kebesaran cinta Allah. Daya cinta Allah inilah yang mengubah pribadi yang beriman dari dalam dan memampukannya untuk melihat dunia dengan mata yang baru. ${ }^{23}$

Paus mengakui bahwa sebagian besar manusia zaman ini tidak melihat adanya hubungan antara kebenaran dan cinta. Bagi mereka, cinta hanya bersentuhan dengan dunia perasaan, bukan dengan kebenaran. Namun, baginya cinta bukanlah perasaan yang fana, walaupun cinta itu melibatkan rasa kasih. Cinta menggerakan dan menuntun manusia untuk membuka diri terhadap sosok yang dicintai, memberikan jalan keluar bagi manusia yang lebih terpusat pada diri sendiri untuk sesama, yaitu membangun hubungan yang panjang dan lama dengan sesama serta bersatu dengan yang lain dan bersatu dengan sosok yang dicintai. ${ }^{24}$

Tujuan cinta adalah bersatu dengan "yang dicintai". Dalam konteks inilah, cinta membutuhkan kebenaran. Hanya ketika cinta memiliki landasan kebenaran, maka cinta itu tidak akan pernah lekang

${ }^{22}$ Lumen Fidei..., no. 26, hlm. 42-43.

${ }^{23}$ Lumen Fidei..., no. 26, hlm. 42-43.

${ }^{24}$ Lumen Fidei..., no. 27, hlm. 43-45. 
Alfonsus Ara, Cinta dan Kebenaran Allah ...

oleh waktu, melampaui setiap masa dan kokoh menopang perjalanan hidup bersama. Apabila tidak memiliki kebenaran, cinta akan jatuh ke dalam tataran perasaan, bisa dan selalu berubah dan tidak tahan uji. Sejatinya, cinta yang berlandaskan pada kebenaran akan menyatukan semua unsur kemanusiaan serta menuntun manusia menuju kehidupan yang penuh dan agung. Tanpa kebenaran, cinta tidak akan mampu menyatukan dan tidak akan mampu membebaskan manusia dari keterpusatan pada diri sendiri dan hal-hal yang fana untuk menciptakan dan menghasilkan hidup yang berbuah. ${ }^{25}$

Cinta dan kebenaran saling membutuhkan: cinta adalah kebenaran dan kebenaran pada hakekatnya adalah kebenaran cinta. “Tanpa cinta, kebenaran menjadi dingin, tidak manusiawi dan menindas". Kebenaran akan menerangi dan memberikan arti bagi perjalanan hidup manusia apabila kebenaran itu bersumber pada cinta. Setiap pribadi yang mencintai sungguh-sungguh menyadari bahwa "cinta adalah pengalaman akan kebenaran". Pengalaman ini akan membuka mata dan hati setiap pribadi yang mencintai untuk melihat dunia dan segalanya dengan cara yang baru, yaitu keberadaan dirinya "dalam persatuan dengan yang dicintainya". ${ }^{26}$

Untuk meneguhkan argumennya ini, Paus Fransiskus mengutip pernyataan Santo Gregorius Agung, "amor ipse notitia est": "cinta pada dirinya sendiri adalah pengetahuan yang mempunyai logikanya sendiri". Logika cinta terletak pada cara melihat dunia dalam relasinya satu dengan yang lain sehingga membentuk pengertian serta menggerakan mata dan hati untuk berbagi isi penglihatan itu sendiri. ${ }^{27}$

Paus Fransiskus juga mengukuhkan argumennya dengan mengutip gagasan William Saint Thierry untuk menjelaskan muatan

\footnotetext{
${ }^{25}$ Lumen Fidei..., no. 27, hlm. 43-45.

${ }^{26}$ Lumen Fidei..., no. 27, hlm. 43-45.

27 Lumen Fidei..., no. 27, hlm. 45.
} 
hakiki yang terkandung dalam Kidung Agung ketika berbicara mengenai pencinta yang berkata kepada yang dicintainya, "Bagaikan merpati, matamu" (Kid 1:15). Paus menegaskan bahwa menurut William, ada dua logika pengetahuan mata, yaitu mata iman dan mata cinta. Pengetahuan iman hanya mampu mengarahkan mata manusia kepada Allah apabila pengetahuan itu menjadi "sebuah pengertian akan cinta yang tercerahkan". 28

Landasan alkitabiah mengenai cinta sebagai sumber pengetahuan dinyatakan ketika Israel mengalami diri mereka dicintai oleh Allah. Allah memilih dan menjadikan mereka sebagai bangsa pilihan-Nya. Pengetahuan iman Israel ini muncul dari isi cinta yang dijanjikan Allah kepada mereka. Pengetahuan iman yang bersumber pada cinta Allah inilah yang menerangi jalan kehidupan mereka. Allah yang diimani Israel dan menerangi jalan hidup mereka adalah cinta dan setia. ${ }^{29}$

Ini berarti bahwa bagi Israel, Allah yang benar adalah Dia yang Mencintai dan Dia yang Setia. Allah yang benar adalah Allah yang setia dan selalu mengingat janji-Nya untuk selalu mencintai Israel, bangsa pilihan-Nya sendiri. Kebenaran Allah ini melampaui batas sejarah kehidupan mereka. ${ }^{30}$

Pengetahuan mengenai kebenaran iman yang bersumber pada perjanjian dengan Allah yang setia ini membentuk hubungan cinta yang mesrah antara Allah dengan Israel dan dengan seluruh bangsa manusia di dunia ini. Allah menyatakan isi cinta-Nya dalam wujud Sabda-Nya yang menjelma. Iman datang dari keterbukaan manusia untuk mendengarkan isi Sabda-Nya. Dengan mendengar, manusia akan mengerti dengan jelas dan pasti mengenai ikatan antara pengetahuan

\footnotetext{
${ }^{28}$ Lumen Fidei..., no. 27, hlm. 45.

${ }^{29}$ Lumen Fidei..., no. 28, hlm. 46.

30 Lumen Fidei..., no. 28, hlm. 46.
} 
Alfonsus Ara, Cinta dan Kebenaran Allah ...

iman dan cinta: cinta menggerakan manusia untuk beriman kepada Dia yang mencintai; iman akan membawa manusia kepada gambaran yang mendalam mengenai Dia yang mencintai; iman dan cinta akan menggerakan manusia untuk mengikuti Dia yang mencintai. Dengan demikian muncul tiga unsur penting yang menuntun manusia untuk menemukan pengetahuan mengenai kebenaran iman, yaitu mendengar, melihat dan mengikuti (percaya). ${ }^{31}$

\section{Beriman sebagai Kunci untuk Mengerti Cinta dan Kebenaran Allah}

Menurut Paus Fransiskus, satu sikap fundamental yang harus dibangun oleh manusia untuk mengerti kedalaman cinta Allah dan semua kebenaran-Nya adalah "beriman". Untuk membuktikan kebenaran argumen-argumennya ini, paus membentangkan fakta-fakta iman, baik dalam Perjanjian Lama maupun dalam Perjanjian Baru untuk memperlihatkan bagaimanakah sikap "iman" itu menjadi dasar untuk mengerti semua pengetahuan mengenai kebenaran-kebenaran Allah.

\section{Perjanjian Lama}

"Mendengar Sabda Allah - "Mengerti-Teguh Jaya"

Paus Fransiskus menegaskan bahwa dalam Perjanjian Lama, satu tindakan fundamental yang menjadi landasan bagi manusia untuk percaya kepada Allah adalah mendengarkan Sabda-Nya. Allah berbicara kepada manusia dan menyatakan kebenaran-kebenaran-Nya yang menjadi landasan kokoh bagi kehidupan manusia melalui sabdaNya. ${ }^{32}$

Menurut Paus Fransiskus, mendengarkan Sabda Allah dan percaya kepada-Nya merupakan kunci untuk mengerti kebenaran-

\footnotetext{
${ }^{31}$ Lumen Fidei..., no. 30-31, hlm. 49-52.

32 Lumen Fidei..., no. 23, hlm. 37-39.
} 
kebenaran Allah. Apabila manusia tidak mendengarkan Sabda Allah, maka sangat mustahil bagi manusia untuk mengerti kebenarankebenaran Allah dan percaya kepada-Nya. Akan tetapi, sikap percaya yang lahir dari aktivitas mendengarkan Sabda Allah ini bukanlah "sikap percaya buta", tanpa mengerti dan memahami inti kebenaran Sabda Allah itu sendiri. Kebenaran-kebenaran Allah yang terkandung dalam Sabda-Nya adalah kebenaran-kebenaran yang sungguh-sungguh diuji kredibilitas dan inteligibilitasnya sehingga bisa dipertanggungjawabkan dengan akal manusia. Kredibilitas dan inteligibilitas kebenarankebenaran Allah inilah yang mematangkan iman manusia kepada Allah. ${ }^{33}$

Relasi apik antara iman dan pengetahuan, terutama pentingnya pengetahuan mengenai kebenaran-kebenaran Allah bagi iman dinyatakan oleh Yesaya kepada Raja Ahaz, "Jika kamu tidak percaya, kamu tidak teguh jaya". Dalam penegasan Yesaya ini, hubungan antara pengetahuan dan iman tampak dalam dua bentuk kata kerja, yaitu "engkau akan percaya" (ta'aminu) dan "kamu teguh jaya" (te'amenu). Pernyataan ini dilontarkan kepada Ahaz ketika Yesaya melihat adanya rasa takut dalam diri Ahaz ketika dia harus berhadapan dengan kekuatan musuhnya. Jalan keluar yang ditempuhnya adalah menerima tawaran untuk bersekutu dengan kerajaan Syria. Pada momen inilah Yesaya mengatakan kepadanya untuk percaya sepenuhnya kepada Allah Israel, Sang Batu Karang yang Teguh. ${ }^{34}$

Yesaya menuntun Ahaz untuk percaya kepada Allah karena Allah sungguh-sungguh dapat dipercaya dan hanya Dialah sosok yang dapat diandalkan. Percaya kepada Allah dan berpegang teguh pada sabda-Nya merupakan tindakan yang sungguh-sungguh masuk akal

${ }^{33}$ Lumen Fidei..., no. 23, hlm. 38-39.

${ }^{34}$ Lumen Fidei..., no. 23, hlm. 38-39. 
Alfonsus Ara, Cinta dan Kebenaran Allah ...

sebab Allah adalah "Amin", "Allah Kebenaran" dan "Dasar Janji Kesetiaan yang Kokoh". ${ }^{35}$

Paus Fransiskus menjelaskan bahwa dalam Kitab Suci versi bahasa Yunani, pernyataan "teguh jaya" diterjemahkan dengan kata "mengerti". Karena tantangan dan tuntunan Yesaya, Ahaz percaya. Dasar kokoh yang dijanjikan Yesaya kepada Ahaz adalah tindakan Allah dalam sejarah manusia: "Allah akan menyelamatkan setiap orang yang percaya kepada-Nya". Ahaz mengerti cara pikir dan cara kerja Allah. Dia percaya bahwa Allah itu setia dan setiap rencana-Nya sungguh indah bagi setiap manusia yang percaya kepada-Nya. ${ }^{36}$

Untuk memperdalam dan mempertajam hubungan antara iman dan pengetahuan mengenai kebenaran-kebenaran Allah, Paus Fransiskus menegaskan kembali sintesi yang dibuat oleh Santo Agustinus berkenaan dengan gagasan "mengerti" dan "teguh jaya". Bagi Agustinus, kebenaran Allah merupakan sandaran utama bagi manusia. Karena itu, semua manusia seharusnya dibentuk dan diteguhkan oleh setiap kebenaran yang keluar dari mulut Allah sebab kebenaran Allah itu sungguh terpercaya. Inti kebenaran Allah dalam sejarah manusia adalah "kehadiran-Nya yang setia di sepanjang sejarah, kemampuan untuk menyatukan waktu dan zaman dan mengumpulkan alur hidup kita yang tercerai-berai" ${ }^{37}$

\section{Mendengar dan Melihat}

Paus Fransiskus juga menjelaskan bahwa dalam Perjanjian Lama, sikap percaya yang lahir dari aktivitas mendengarkan Sabda Allah serentak menggerakan hasrat manusia untuk melihat wajah Allah.

\footnotetext{
${ }^{35}$ Lumen Fidei..., no. 23, hlm. 37-39.

${ }^{36}$ Lumen Fidei..., no. 23, hlm. 37-39.

37 Lumen Fidei..., no. 23, hlm. 37-39.
} 
Walaupun demikian, kedua sikap dasar ini memiliki aksen yang berbeda. $38^{38}$

Sikap mendengar lebih menekankan panggilan, keterbukaan dan kepatuhan pribadi terhadap isi Sabda Allah dan kebenaran-kebenaranNya. Sedangkan dalam hasrat untuk melihat Wajah Allah terbangun komitmen iman manusia untuk menyerahkan seluruh diri dan kehidupannya kepada Allah dan hidup sesuai dengan rencana-Nya. ${ }^{39}$

\section{Iman dan Pengetahuan mengenai Kebenaran Allah}

Berinspirasikan pada naskah kenabian, Paus Fransiskus menyimpulkan bahwa dalam beriman, manusia Perjanjian Lama membutuhkan pengetahuan mengenai kebenaran-kebenaran Allah agar mereka bisa berdiri tegak dan berjalan ke depan dengan langkah pasti. Iman tanpa pengetahuan mengenai kebenaran-kebenaran Allah tidak menyelamatkan sebab tidak memberikan pijakan yang pasti. Iman tanpa pengetahuan mengenai kebenaran-kebenaran Allah hanya menjadi sebuah kisah indah sebab hanya menyingkapkan hasrat mengenai kebahagiaan sesaat, namun menipu. ${ }^{40}$

Iman tanpa pengetahuan mengenai kebenaran-kebenaran Allah hanya memberikan rasa aman dan nyaman dalam waktu sekejab sebab tidak berakar dan akan mudah diterpa arus zaman. Raja Ahaz tidak akan pernah bersedia mempertaruhkan hidupnya dan keselamatan kerajaannya apabila sikap imannya hanya tergerak dalam batas perasaan. Sikap imannya yang teguh jaya kepada Allah lahir karena dia percaya dan mengerti kebenaran-kebenaran Allah yang menawarkan cahaya baru dalam kehidupannya. Dia percaya dengan sikap imannya

\footnotetext{
38 Lumen Fidei..., no. 29, hlm. 48-49.

39 Lumen Fidei..., no. 29, hlm. 48-49.

${ }^{40}$ Lumen Fidei..., no. 24, hlm. 39.
} 
Alfonsus Ara, Cinta dan Kebenaran Allah ...

yang teguh jaya kepada Allah karena kebenaran-kebenaran Allah "lebih hebat dari perhitungannya". Dalam iman, dia melihat jauh ke depan dengan satu keyakinan dan harapan bahwa Allah selalu setia pada perjanjian dan janji-janji-Nya. ${ }^{41}$

\section{Perjanjian Baru}

Fides ex Auditu

Menurut Paus Fransiskus, dalam Perjanjian Baru hubungan antara iman dan pengetahuan mengenai kebenaran-kebenaran Allah ditemukan dalam perjanjian antara Allah dengan manusia, ciptaan-Nya: Allah adalah Cinta. Karena cinta-Nya, Allah berinisiatif untuk membangun hubungan cinta dengan manusia. Allah menyatakan kedalaman cinta-Nya kepada manusia dalam tindakan-Nya, yaitu setia. Cinta dan kesetiaan Allah kepada manusia dinyatakan dalam dua tindakan-Nya, yaitu menyampaikan Sabda dan kebenaran-Nya supaya didengar dan dimengerti oleh manusia serta rela memberikan diri-Nya demi keselamatan manusia. ${ }^{42}$

Rasul Paulus melukiskan hubungan antara Allah yang menyatakan cinta dan kesetiaan-Nya melalui Sabda dan kebenaran-Nya supaya didengar dan dimengerti oleh manusia dengan pernyataan ini, "fides ex auditu", "iman datang dari pendengaran" (Rom 10:17). Dengan rumusan ini, Rasul Paulus menyatakan bahwa pengetahuan mengenai kebenaran-kebenaran Allah yang didengar, dimengerti dan diimani oleh manusia sungguh-sungguh "benar" (tidak sesat) sebab isi kebenaran itu bersumber dari cinta Allah yang dinyatakan dalam kesetiaan-Nya, yaitu kehadiran-Nya dalam wujud "Pribadi". Dialah Yesus Kristus, Sabda Kekal Allah yang Menjelma menjadi Manusia.43

\footnotetext{
${ }^{41}$ Lumen Fidei..., no. 24, hlm. 39-40.

42 Lumen Fidei..., no. 29, hlm. 47.

${ }^{43}$ Lumen Fidei..., no. 27, hlm. 47.
} 
Sabda-Nya adalah kebenaran sebab suara Sabda-Nya nyata dalam Pribadi yang bisa didengar, sosok-Nya dikenal dan daya SabdaNya menggerakan pribadi-pribadi manusia yang mendengar untuk patuh dan taat hingga bersedia mengikuti-Nya. Menurut Paulus, kesediaan pribadi-pribadi untuk mendengar suara Sabda-Nya dan memutuskan untuk mengikuti-Nya semata-mata karena di dalam Sabda-Nya terkandung pengetahuan mengenai kebenaran-kebenaranNya. Isi kebenaran itu bersumber dari cinta-Nya yang agung dan mulia dan dinyatakan dalam kesetiaan-Nya. ${ }^{4}$

Mendengar dan Melihat

Paus Fransiskus menjelaskan bahwa dalam Perjanjian Baru hubungan antara iman dan pengetahuan mengenai kebenarankebenaran Allah juga dinyatakan dalam kerekatan antara aktivitas "mendengar" dan "melihat". Sikap mendengar yang melahirkan iman hanya mungkin terbentuk apabila disertai dengan "hasrat untuk melihat wajah Allah" sendiri.45 "Pendengaran menekankan panggilan dan kepatuhan pribadi [...], sedangkan, "Penglihatan memberikan sebuah gambaran akan seluruh perjalanan dan mengizinkannya untuk berada dalam keseluruhan rencana Allah". Apabila keterbukaan untuk mendengar tidak disertai dengan hasrat untuk melihat, maka pengenalan akan kebenaran-kebenaran Allah tidak utuh. “Tanpa gambaran, kita hanya memiliki bagian-bagian yang tidak berhubungan dari satu keutuhan yang tidak kita ketahui" ${ }^{46}$

Hubungan antara aktivitas "mendengar dan melihat" yang melahirkan iman dinyatakan secara jelas oleh penginjil Yohanes. Bagi Yohanes, iman lahir, tumbuh dan berkembang karena adanya aktivitas "mendengar dan melihat". Iman bertumbuh dan berkembang dalam diri

\footnotetext{
44 Lumen Fidei..., no. 29, hlm. 47.

45 Lumen Fidei..., no. 29, hlm. 47-48.

46 Lumen Fidei..., no. 29, hlm. 48-49.
} 
Alfonsus Ara, Cinta dan Kebenaran Allah ...

para murid ketika mereka mendengar Sabda Yesus, Sang Guru. Dalam Sabda-Nya, mereka menangkap satu pengetahuan yang khas, yaitu cinta. Bagi para murid, cinta Yesus adalah kebenaran karena dinyatakan dalam tindakan-Nya. Mereka mendengar dan mengenal suara kebenaran-Nya, yaitu suara Gembala yang Baik dan memutuskan untuk mengikuti-Nya. ${ }^{47}$

Akan tetapi, aktivitas mendengar hanya mampu menggerakan para murid untuk mengikuti Yesus karena diteguhkan oleh penglihatan mereka atas segala sesuatu yang dilakukan Yesus sendiri. Mereka "melihat tanda-tanda yang dikerjakan Yesus" dan tanda-tanda itu menuntun mereka untuk beriman kepada-Nya. "Kedua murid itu mendengar apa yang dikatakannya itu, lalu mereka pergi mengikuti Yesus" (Yoh 1:37). Fakta yang sama juga terjadi dalam diri orang Yahudi setelah melihat peristiwa kebangkitan Lazarus. Setelah mereka "menyaksikan sendiri apa yang telah dibuat Yesus, mereka percaya kepada-Nya" (Yoh 11:45).48

Dengan demikian tampak bahwa aktivitas melihat menjadi alasan yang memotivasi para murid dan orang Yahudi lainnya untuk percaya dan masuk ke kedalaman misteri hidup Yesus sendiri. Ketika melihat kubur kosong, Yohanes teringat akan perkataan Yesus bahwa Dia harus mati dan bangkit pada hari ketiga. Pada saat itu, dia langsung "percaya". Demikian juga dengan Maria Magdalena: ketika dia melihat Yesus, dia ingin menyentuh dan ingin bersama Yesus.

Pengalaman Yohanes dan Maria Magdalena ini dilukiskan Paus Fransiskus dengan bahasa yang indah, "Paskah pagi bergerak dari Yohanes yang berdiri dalam kegelapan pagi di depan kubur yang kosong, "melihat dan percaya" (Yoh 20,8), melalui Maria Magdalena yang setelah melihat Yesus "(Yoh 20:14) dan ingin bersama-Nya". Penglihatan mereka atas segala sesuatu yang terjadi di makan Tuhan

\footnotetext{
47 Lumen Fidei..., no. 30, hlm. 49.

${ }^{48}$ Lumen Fidei..., no. 30, hlm. 49.
} 
dan perjumpaan mereka dengan Tuhan sendiri di makam-Nya menuntun mereka untuk merenung dan masuk ke dalam isi sabda-Nya sendiri bahwa Dia bangkit dan hidup kembali dan "Ia akan pergi kepada Bapa". Perjumpaannya antara Yesus yang bangkit memotivasi Maria Magdalena untuk berani bersaksi di hadapan para murid-Nya sendiri, “Aku telah melihat Tuhan!" (Yoh 20:18). ${ }^{49}$

Paus Fransiskus meneguhkan keyakinannya ini dengan mengutip gagasan Thomas Aquinas ketika berbicara mengenai oculata fides (iman yang melihat) dalam diri para Rasul terhadap "kehadiran tubuh Tuhan yang bangkit". Dengan "mata mereka sendiri, mereka melihat Yesus yang bangkit dan mereka percaya". ${ }^{50}$

Bagi Paus Fransiskus, aktivitas mendengar dan melihat menjadi paduan yang rekat dan penuh daya untuk menumbuhkan iman kepada Yesus karena Dia adalah sosok historis yang bisa dilihat dan didengar. Dia adalah Sabda Kekal Allah yang menjelma menjadi manusia. Dalam diri-Nya, manusia mengenal wajah Allah dan kebenaran-kebenaranNya. Karena itu, Paus Fransiskus menegaskan bahwa Sabda Kebenaran Allah harus menjelma menjadi manusia supaya Dia bisa membagi pengetahuan yang khas mengenai cinta dan kebenaran-kebenaran Allah kepada manusia. ${ }^{51}$

Paus juga menjelaskan bahwa dalam keempat Injil dinyatakan dengan jelas kalau Yesus itu sungguh-sungguh Sabda Kebenaran Allah. Apabila manusia mendengar, melihat dan mengimani Sabda Kebenaran-Nya, manusia akan menerima kehidupan yang penuh cahaya sebab "kebenaran yang melekat pada iman adalah pewahyuan Bapa dalam Putra yang menjadi daging dan tindakan duniawi-Nya,

\footnotetext{
${ }^{49}$ Lumen Fidei..., no. 30, hlm. 50-51

50 Lumen Fidei..., no. 30, hlm. 51.

51 Lumen Fidei..., no. 30, hlm. 51
} 
Alfonsus Ara, Cinta dan Kebenaran Allah ...

sebuah kebenaran yang diartikan sebagai "kehidupan yang dipenuhi cahaya" Yesus". 52

Dengan pernyataannya ini, Paus Fransiskus memperlihatkan hakikat dari akitivitas mendengar dan melihat pada titik yang lebih dalam dari iman dan pengetahuan mengenai kebenaran-kebenaran Allah. Diyakininya bahwa iman dan pengetahuan mengenai kebenarankebenaran Allah itu "tidak menyesatkan" sebab "tidak mengarahkan penglihatan kita pada kebenaran yang semata datang dari dalam diri" manusia sendiri. Kebenaran yang dibukakan oleh iman adalah kebenaran yang berpusat pada perjumpaan dengan Kristus sendiri", serta kebenaran yang lahir dari buah "permenungan akan hidup-Nya dan kesadaran akan kehadiran-Nya. ${ }^{53}$

Iman yang muncul dari pendengaran akan membawa manusia yang beriman untuk melihat kenyataan yang lebih mendalam dari kehidupan Allah sendiri. "Barangsiapa percaya kepada-Ku, ia bukan percaya kepada-Ku, tetapi kepada Dia, yang telah mengutus Aku dan barangsiapa melihat $\mathrm{Aku}$, ia melihat Dia yang mengutus $\mathrm{Aku}^{\prime \prime}$ (Yoh 12:44-45). Hakikat terdalam yang terkandung dalam aktivitas mendengar dan melihat ini akhirnya terangkum dalam penegasan Yesus sendiri bahwa mereka akan menyaksikan dengan lebih mendalam apa yang mereka lihat dan mampu menyatakan iman mereka atas Putra Allah yang duduk di sisi kanan Bapa. "Jikalau engkau percaya engkau akan melihat kemuliaan Allah" (Yoh 11:40). ${ }^{54}$

\footnotetext{
52 Lumen Fidei..., no. 30, hlm. 49-50.

53 Lumen Fidei..., no. 30, hlm. 50-51.

54 Lumen Fidei..., no. 30, hlm. 49-50.
} 


\section{Cinta dan Kebenaran Allah dalam Persekutuan Hidup Bersama}

\section{Cahaya Kehidupan}

Paus menjelaskan bahwa Allah menyatakan cinta dan kebenaran-Nya dalam Sabda-Nya yang menjelma menjadi manusia, yaitu Yesus Kristus. Apabila manusia mendengarkan Sabda-Nya, maka manusia akan percaya kepada-Nya dan mengerti mengenai arti pemberian cinta dan kebenaran-kebenaran-Nya. Cinta dan kebenarankebenaran Allah yang dinyatakan dalam Sabda-Nya adalah cinta dan kebenaran yang kredibel dan inteligibel, sebab bisa dicerna, dijelaskan dan dipertanggungjawabkan dengan akal manusia. ${ }^{55}$

Beriman pada cinta dan kebenaran-kebenaran Allah yang diperoleh dari pendengaran akan Sabda-Nya berarti membiarkan Allah menjadi cahaya penerang dan penuntun bagi setiap langkah dan pergerakan hidup. Cinta dan kebenaran Allah yang diimani akan menerangi semua aspek kemanusiaan, baik keberadaannya sebagai manusia maupun pikiran dan kehendak manusia. Cinta dan kebenaran Allah akan membuka cakrawala baru dan menuntun manusia untuk menemukan orientasi hidup. ${ }^{56}$

Paus Fransiskus menegaskan bahwa tiada terang cinta dan kebenaran yang paling bercahaya untuk menerangi kehidupan manusia, selain terang cinta dan kebenaran Allah sendiri dalam diri Yesus Kristus. Terang cinta dan kebenaran Allah dalam diri Yesus Kristus melampaui semua kebenaran akali manusia sebab terang-Nya adalah cinta-Nya yang terpancar dalam hidup dan tindakan-Nya sendiri agar manusia selamat serta mengupayakan hidup yang bermakna, yaitu hidup dalam kuasa cinta satu terhadap yang lain. ${ }^{57}$

55 Lumen Fidei..., no. 15-16, hlm. 22-25.

56 Lumen Fidei..., no. 32-33, hlm. 53-56.

57 Lumen Fidei..., no. 34-35, hlm. 58-62. 
Alfonsus Ara, Cinta dan Kebenaran Allah ...

Bagi bangsa-bangsa dan budaya-budaya manusia yang berdiam di alam ini, kebenaran itu berada pada tataran akal. Namun dalam iman kristiani, kebenaran yang menjadi terang dan cahaya hidup manusia berada dalam diri Sang Terang, yaitu Sang Sabda yang menjelma menjadi manusia. Dia adalah Sang Terang Cinta yang penuh dan defenitif dari Allah bagi manusia. Dalam terang cinta-Nya, manusia menemukan bahwa cinta yang menggerakan vitalitas dan menyatukan manusia satu dengan yang lainnya adalah isi cinta-Nya sendiri, yaitu cinta "yang rela membagikan dan memberikan diri demi kebahagiaan yang lain". Inilah finalitas cinta: "tiada kebahagiaan yang diraih oleh manusia, selain kebahagiaan yang diraih karena rela memberikan diri demi kebahagiaan yang lain, seperti Yesus Kristus sendiri". Dalam terang cinta ini, semua relasi antara manusia disinari sehingga mampu membangun hidup dalam persekutuan cinta antara satu dengan yang lain. 58

Dalam muatan ini patut ditegaskan bahwa akal manusia harus diterangi dan disatukan dalam cakrawala iman sebab tiada kebenaran yang paling rasional, terang, jelas dan masuk akal, selain kebenaran iman yang berasal dan digerakan oleh cinta. Allah adalah cinta dan terang-Nya terpancar dari kedalaman dan kecerahan cinta-Nya. CintaNya akan memberikan pencerahan serta membawa manusia ke arah hidup yang baru, yaitu hidup yang indah dalam persekutuan dan pemberian cinta. Sosok Allah ini tidak hanya ditemukan melalui pendengaran (Sabda-Nya dalam Kitab Suci, "Ambil dan bacalah"), tetapi sungguh-sungguh tampak dalam pribadi yang tinggal bersama dan berbicara dengan manusia serta menemani setiap pergerakan manusia menuju kesempurnaan hidup dalam terang cinta. ${ }^{59}$

Cahaya sungguh-sungguh menjadi cahaya Sabda karena terang cahaya-Nya itu nyata dalam "wajah personal" yang mencintai dan

\footnotetext{
${ }^{58}$ Lumen Fidei..., no. 25, hlm. 40-42.

${ }^{59}$ Lumen Fidei..., no. 32-34, hlm. 53-58
} 
memberikan diri-Nya demi keselamatan dan kebahagiaan yang dicintai. Cahaya Sabda yang nyata dalam wajah personal ini memanggil, menuntun dan menerangi jalan hidup manusia dari dalam untuk masuk ke dalam cahaya hidup-Nya, yaitu cahaya cinta dan hidup saling mencintai. Cahaya-Nya adalah kebenaran dan kebenaran-Nya adalah kebenaran cinta. Kebenaran-Nya tidak bisa direduksikan ke dalam otentisitas obyektif perorangan sebab kebenaran-Nya lahir dari perjumpaan personal dengan-Nya dan dengan sesama. Kebenaran cinta menggerakan manusia untuk hidup dalam kuasa cinta, membebaskan diri dari keterkurungan pribadi serta berjuang untuk menjadi bagian dari kesejahteraan umum. ${ }^{60}$

Karena kebenaran-Nya adalah kebenaran cinta, maka kebenaranNya tidak bisa dipaksakan. Kebenaran cinta muncul dari hati, merasuk dalam hati dan inti diri manusia sendiri, maka kebenaran itu akan menuntun manusia untuk bersikap rendah hati satu terhadap yang lain. Sikap ini terbangun karena adanya kesadaran bahwa kebenaran cinta itu bukanlah milik pribadi, melainkan karena kebenaran itu memeluk dan memiliki pribadi manusia. Kebenaran cinta tidak berada di luar diri manusia, tetapi tinggal dalam diri manusia sendiri. 61

\section{Cahaya bagi semua Pencarian Manusia}

Menurut Paus Fransiskus, keterarahan manusia terhadap Allah dan beriman kepada-Nya sudah tertanam dalam kodrat manusia sendiri. Manusia berusaha mengenal Allah melalui alam ciptaan dan isinya serta pengalaman dan pergumulan hidupnya. Namun, usaha manusia untuk mengenal Allah tidak terbatas pada pengakuan bahwa Allah itu sungguh-sungguh ada. Pengenalan Allah yang benar harus melibatkan pikiran, hati dan seluruh kepribadian manusia. Mengenal Allah berarti mengakui bahwa Dia adalah dasar dan tujuan hidup

\footnotetext{
${ }^{60}$ Lumen Fidei..., no. 33-34 hlm. 56-57

${ }^{61}$ Lumen Fidei..., no. 34, hlm. 56-58.
} 
Alfonsus Ara, Cinta dan Kebenaran Allah ...

manusia. Pribadi-pribadi yang sungguh-sungguh mengenal Allah adalah pribadi-pribadi yang sungguh-sungguh percaya bahwa segala sesuatu, terutama hidupnya sendiri berasal dari Allah serta melihat dan menemukan tanda-tanda kehadiran Allah dalam pengalaman hidup sehari-hari. ${ }^{62}$

Karena alasan ini, maka Paus Fransiskus mengajak agar: pertama, semua bentuk penglihatan dan pencarian akali manusia dalam bentuk apa pun harus diterangi oleh cahaya cinta Allah sendiri. Manusia harus sadar bahwa semua cahaya bersumber dan berpusat pada Allah, yaitu dalam "hidup-Nya yang bercahaya, yang mengungkapkan asal dan tujuan sejarah". Manusia juga harus sadar bahwa "tidak ada pengalaman manusiawi, tidak ada perjalanan manusia menuju Allah yang tidak dapat diangkat, diterangi dan disucikan oleh cahaya" Allah sendiri. Karena itu manusia umumnya dan manusia kristiani khususnya harus masuk ke dalam cahaya Allah supaya semakin mengerti dan memahami bahwa semua pergerakan hidup anusia hanya terarah kepada Allah. ${ }^{63}$

Paus Fransiskus yakin, apabila penglihatan dan pencarian akali manusia diterangi oleh cahaya iman yang "disatukan dengan kebenaran cinta", maka semua bentuk penglihatan akali akan bermanfaat dan berdaya bagi manusia. Cahaya iman dan cinta akan menguatkan para ilmuwan untuk senantiasa membuka diri kepada dunia dengan segala kekayaannya. Cahaya iman dan cinta juga akan membangkitkan daya kritis dalam diri para ilmuwan agar mereka tidak berpuas diri pada rumusan yang diciptakan serta membantu mereka untuk menyadari bahwa alam semesta jauh lebih besar dan luas dari ilmu-ilmu akali mereka. Cahaya iman dan cinta akan memperluas cakrawala akali para

\footnotetext{
${ }^{62}$ Lumen Fidei..., no. 35, hlm. 59-61.

${ }^{63}$ Lumen Fidei..., no. 35, hlm. 59-61.
} 
ilmuwan agar mampu memancarkan sinar yang lebih terang benderang kepada dunia dengan berlandaskan pada kebenaran hati dan cinta. ${ }^{6}$

Kedua, semua manusia seharusnya bersedia dibimbing dan dituntun oleh Allah sendiri. Dalam koridor iman ini, paus meyakinan manusia beriman bahwa Yesus Kristus adalah Jalan, Kebenaran, dan Kehidupan (Yoh 14:6) menuju Allah. Dia adalah kebenaran bagi semua manusia. Kebenaran-Nya nyata dalam kesesuaiannya antara pikiran tentang Dia dan realitas diri-Nya serta kesesuaian antara apa yang diimani dengan realitas yang ada di dalam diri Yesus Kristus sendiri. Karena iman adalah sebuah jalan, maka iman berkaitan juga dengan hidup manusia yang walaupun tidak percaya, namun berhasrat untuk percaya dan terus mencari Allah. Cahaya kebenaran-Nya hendaknya menyinari semua manusia karena Dia adalah terang yang benar yang menyinari setiap orang. ${ }^{65}$

Iman adalah cahaya. Iman akan menerangi jalan hidup manusia untuk menjelajahi cakrawala hidup agar manusia lebih mengenal obyek cinta manusia yang sesungguhnya, yaitu Allah dalam diri Yesus Kristus sendiri. Dalam konteks inilah Paus Fransiskus menjelaskan perihal kegunaan teologi untuk menjelaskan dan mempertanggungjawabkan secara rasional mengenai iman kepada Allah dan kebenaran-kebenaranNya.

Paus Fransiskus mengakui bahwa teologi kristiani lahir dari hasrat manusia untuk mengenal Allah dan kebenaran-kebenaran-Nya. Melalui teologi, manusia dimungkinkan untuk mencari dan menemukan pengertian yang menyeluruh mengenai pewahyuan Allah yang berpuncak dalam diri Yesus Kristus. Teologi tidak mungkin dirumuskan dalam sebuah sistem yang kritis tanpa iman, karena teologi merupakan bagian dari proses beriman. 66

\footnotetext{
${ }^{64}$ Lumen Fidei..., no. 34, hlm. 56-58.

65 Lumen Fidei..., no. 35, hlm. 59-62.

${ }^{66}$ Lumen Fidei..., no. 36, hlm. 62.
} 
Alfonsus Ara, Cinta dan Kebenaran Allah ...

Pengetahuan manusia mengenai Allah sangat terbatas. Manusia tidak akan mampu mengenal Allah dengan kekuatannya sendiri dengan mengandalkan daya refleksi manusiawinya. Allah hanya dapat dikenal melalui penyataan diri-Nya kepada manusia dalam Putera-Nya yang menjelma menjadi manusia. Karena itu, manusia harus membuka pikiran dan hatinya untuk dicerahi, dibimbing dan diberdayakan oleh Allah sendiri dengan kekuatan Roh-Nya. Dalam konteks ini, manusia membutuhkan iman menerangi pemahamaan insaninya. ${ }^{67}$

Sebagai ilmu iman, teologi mempelajari wahyu Allah. Teologi lebih dari sekadar upaya akali manusia untuk menganalisa dan memahami pengalaman empiris mengenai Allah. Teologi bukan sekedar wacana mengenai Allah, melainkan usaha manusia untuk menerima dan memahami secara mendalam mengenai Sabda Allah yang disampaikan kepada umat-Nya. Teologi menuntut kerendahan hati untuk menyadari dan mengakui keterbatasan manusiawi di hadapan misteri-Nya yang dalam sembari berusaha untuk meneliti disiplin ilmiah yang selaras dengan akal budi mengenai kekayaan yang tidak terbatas dari misteri ini. ${ }^{68}$

Teologi juga berperan untuk membentuk iman Gereja. Cahaya teologi adalah cahaya subjek yang percaya, yaitu Gereja. Implikasinya, teologi harus melayani iman kristen, harus bekerja dengan penuh kerendahan hati untuk melindungi dan memperdalam iman setiap orang, terutama umat beriman biasa. Iman yang benar mengarahkan akal budi untuk membuka dirinya pada cahaya yang datang dari Allah. Akal budi yang dibimbing dan dicerahi oleh cinta akan menemukan isi kebenaran Allah dan pengetahuan yang utuh dan mendalam mengenai Allah sendiri. ${ }^{69}$

\footnotetext{
${ }^{67}$ Lumen Fidei..., no. 36, hlm. 63.

68 Lumen Fidei..., no. 36, hlm. 59-61.

69
} 


\section{Penutup}

Cinta Allah adalah kebenaran sebab dinyatakan dalam tindakanNya, yaitu kesetiaan untuk mencintai manusia hingga rela memberikan diri-Nya demi keselamatan dan kebahagiaan manusia. Allah yang Mahacinta dan Mahasetia tidak pernah mengingkari cinta-Nya kepada manusia, walaupun isi cinta-Nya dikhianati oleh manusia.

Cinta Allah adalah kebenaran dan kebenaran-kebenaran Allah yang dinyatakan dalam Sabda-Nya yang menjelma menjadi manusia, yaitu Yesus Kristus adalah kebenaran cinta. Cinta dan kebenaran Allah yang dinyatakan dalam diri Yesus Kristus menjadi cahaya benderang untuk menerangi dan memberikan arti bagi perjalanan hidup manusia. Setiap pribadi yang mencintai harus sungguh menyadari bahwa "cinta adalah pengalaman akan kebenaran". Pengalaman ini akan membuka mata dan hati setiap pribadi yang mencintai untuk melihat dunia dan segalanya dengan cara yang baru, yaitu keberadaan dirinya "dalam persatuan dengan yang dicintainya"

$$
===0000===
$$


Alfonsus Ara, Cinta dan Kebenaran Allah ...

\section{DAFTAR PUSTAKA}

Fransiskus, Paus. Ensiklik Lumen Fidei. Diterjemahkan oleh Alb. Deby Setiyanto (Yogyakarta: Kanisius 2014).

Benediktus XVI, Paus. Ensiklik Deus Caritas Est. Diterjemahkan oleh Piet Go, O.Carm (Jakarta: Dokpen KWI 2005).

Ensiklik Caritas In Veritate (Kasih dalam Kebenaran), diterjemahkan oleh B. R. Agung Prihartana, MSF (Jakarta: Dokpen KWI 2014).

Yohanes Paulus II, Paus. Anjuran Apostolik mengenai Peranan Keluarga Kristen dalam Dunia Modern Familiaris Consortio. Diterjemahkan oleh R. Hardawiryana (Jakarta: Departemen Dokumentasi dan Penerangan KWI 1993). 